\title{
Multiple, extensive intracardiac thrombi in patient with ischaemic cardiomyopathy
}

\author{
Nonthikorn Theerasuwipakorn, ${ }^{1}$ Chonthicha Lerdkhonsan, ${ }^{2}$ Pairoj Chattranukulchai, ${ }^{1}$ \\ Weerapat Kositanurit ${ }^{3}$
}

\begin{abstract}
${ }^{1}$ Medicine, Division of Cardiovascular Medicine, Chulalongkorn University, Bangkok, Thailand ${ }^{2}$ Radiology, King Chulalongkorn Memorial Hospital, Bangkok, Thailand

${ }^{3}$ Physiology, Chulalongkorn University, Bangkok, Thailand
\end{abstract}

Correspondence to Dr Pairoj Chattranukulchai; pairoj.md@gmail.com

Accepted 19 December 2020

Check for updates

(c) BMJ Publishing Group Limited 2021. No commercial re-use. See rights and permissions. Published by BMJ.

To cite: Theerasuwipakorn $\mathrm{N}$, Lerdkhonsan C,

Chattranukulchai $\mathrm{P}$, et al. BMJ Case Rep 2021;14:e239989. doi:10.1136/bcr-2020-

239989

\section{DESCRIPTION}

A 52-year-old man with ischaemic cardiomyopathy from severe triple coronary artery disease was referred to our hospital due to recurrent acute decompensated heart failure (ADHF). He has a history of myocardial infarction diagnosed 5 months ago. On admission, the patient had symptoms and signs of lung congestion with poor tissue perfusion (wet and cold). A 12-lead ECG revealed sinus rhythm, left axis deviation and poor R progression. An echocardiogram showed severely dilated left ventricular (LV) chamber and severely impaired systolic function with an ejection fraction of $18 \%$. There were regional myocardial wall thinning and akinesis of basal-to-apical anterior, septal and inferior walls. An apical LV thrombus was noted. A cardiovascular magnetic resonance (CMR) was scheduled to evaluate myocardial viability, which showed that the LV myocardium in the territory of left anterior descending, and right coronary arteries were non-viable on delayed enhancement images (bright areas on figure 1B). The right ventricular systolic function was normal with an ejection fraction of $50 \%$. Moreover, a large right atrial (RA) thrombus and three $\mathrm{LV}$ thrombi at apical, anterior and inferior walls were visualised with largest measuring $3.2 \times 2.2 \mathrm{~cm}$ (arrows on figure 1). The laboratory workup for hypercoagulable states was unremarkable. The patient was treated with inotropic agents, diuretics and warfarin. Guideline-directed medical therapy was subsequently initiated when the ADHF improved. After a multidisciplinary heart team discussion, the patient has been listed to heart transplantation for the definitive

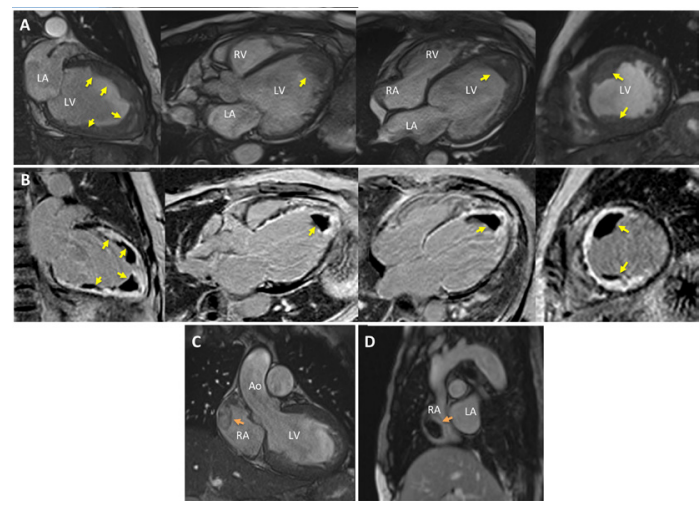

Figure 1 Cardiovascular magnetic resonance images demonstrate multiple left ventricular thrombi on cine images (yellow arrows (A)), and on delayed enhancement images (yellow arrows, (B)). There is also a large right atrial thrombus. (arrows, (C and D)). Ao, aorta; LA, left atrium; $L V$, leftventricle; $R A$, rightatrium; $R V$, rightventricle.

\section{Patient's perspective}

I was frightened when the doctor first told me that I had several blood clots in my heart. I later on was glad to have it detected early and treated before it goes to my brain.

\section{Learning points}

Multiple sites of left ventricular thrombi with right atrial (RA) appendage thrombus in ischaemic cardiomyopathy with sinus rhythm are rare.

- It has been hypothesised that the prothrombotic state from chronic liver congestion and synthetic dysfunction could account for the thrombus formation in area without blood flow stagnation such as RA.

treatment. A 2-month follow-up imaging demonstrated minimal change in size of thrombi.

The LV thrombus is not uncommonly found in patients with ischaemic cardiomyopathy. ${ }^{1}$ However, multiple sites of LV thrombi with RA appendage thrombus in ischaemic cardiomyopathy with sinus rhythm are rare. ${ }^{2-4}$ The Virchow's triad, which consists of blood stasis, endothelial injury and hypercoagulable state, could explain the intracardiac thrombus formation like other vascular thrombi. In our case, the LV thrombi are located at the non-viable and akinetic segments as a result of blood flow stagnation.

However, the blood in RA is not stagnant thus the possible explanation for the RA thrombus formation is likely to be the prothrombotic state from chronic liver congestion and synthetic dysfunction. ${ }^{2-4}$ The CMR is considered as the gold standard modality to detect an intracardiac thrombus with the highest sensitivity, specificity, positive predictive value and negative predictive value. ${ }^{1} \mathrm{An}$ intracardiac thrombus can cause an embolic event leading to catastrophic morbidity and mortality. Early detection with prompt initiation of anticoagulant is the key management to prevent disability and improve survival.

Contributors NT, WK and PC cared for the patient and wrote the report. CL collected the data. All authors read and approved the final version of the report.

Funding The authors have not declared a specific grant for this research from any funding agency in the public, commercial or not-for-profit sectors. 
Images in...

Patient consent for publication Obtained.

Provenance and peer review Not commissioned; externally peer reviewed.

\section{REFERENCES}

1 Whalen H, Dako F, Patel P, et al. Role of imaging for suspected cardiac thrombus. Curr Treat Options Cardiovasc Med 2019;21:81-92.
2 Falcone AM, Matter GJ, Schussler JM. Right atrial appendage thrombus found in a patient in normal sinus rhythm with normal right ventricular systolic function. Echocardiography 2013;30:E70-1.

3 Polić S, Rumboldt Z, Rakić D. Rapid dissolution of right atrial thrombus in a patient with congestive cardiomyopathy. G Ital Cardiol 1985;15:809-11.

4 Kluge J-G, Jurisch D, Tarr A, et al. Right atrial free-floating thrombus in dilated cardiomyopathy. Eur J Echocardiogr 2011;12:798.

Copyright 2021 BMJ Publishing Group. All rights reserved. For permission to reuse any of this content visit

https://www.bmj.com/company/products-services/rights-and-licensing/permissions/

BMJ Case Report Fellows may re-use this article for personal use and teaching without any further permission.

Become a Fellow of BMJ Case Reports today and you can:

- Submit as many cases as you like

- Enjoy fast sympathetic peer review and rapid publication of accepted articles

- Access all the published articles

Re-use any of the published material for personal use and teaching without further permission

Customer Service

If you have any further queries about your subscription, please contact our customer services team on +44 (0) 2071111105 or via email at support@bmj.com.

Visit casereports.bmj.com for more articles like this and to become a Fellow 